\title{
TUNING OF PRODUCT SELECTIVITY IN THE CONVERSION OF ETHANOL TO HYDROCARBONS OVER H-ZSM-5 BASED ZEOLITE CATALYSTS
}

Thanh Khoa Phunga ${ }^{a}$, Randy Radikapratama ${ }^{a}$, Gabriella Garbarino ${ }^{a}$, Alberto Lagazzo ${ }^{a}$, Paola Riani $^{\mathrm{b}}$, Guido Busca ${ }^{\mathrm{a}, *}$

aUniversity of Genova, Department of Civil, Chemical and Environmental Engineering, p. J.F. Kennedy 1, 16129 Genova, Italy

${ }^{b}$ Università degli Studi di Genova, Dipartimento di Chimica e Chimica Industriale (DCCI), Via Dodecaneso 31, I-16146 Genova, Italy

$\left({ }^{*}\right)$ corresponding author: Guido.Busca@unige.it (G. Busca)

Tel: (+39) 010353 6024, Fax: (+39) 0103536028

\section{Abstract}

Conversion of ethanol to hydrocarbons was investigated over $\mathrm{H}-\mathrm{ZSM}-5$ zeolite and its modification by addition of phosphorus, iron and nickel. Reaction is realized in a tubular flow reactor at atmospheric pressure. Catalyst characterization was performed by UV-vis, TG-DTA, $\mathrm{XRD}, \mathrm{NH}_{3}$ TPD, and IR spectroscopy of the surface $\mathrm{OH}$ groups and of adsorbed pyridine. High $\mathrm{P}$ content enhances the selectivity to lower olefins, in particular ethylene, as also occurs in the case of Fe addition. Over $\mathrm{Ni}$-modified zeolites, $\mathrm{C}_{4}$ and aromatics production is promoted. The role of acidity on the conversion path is briefly discussed.

Keywords: H-ZSM-5, ethanol, phosphorus, aromatics, olefins, $\mathrm{NH}_{3}-\mathrm{TPD}$.

\section{Introduction}

Bioethanol coming from cellulosics could become, in the frame of a new organic chemical industry based on renewables, a key primary intermediate. A number of secondary intermediates can be obtained from it. Catalytic dehydration over oxides and zeolites (including H-ZSM-5 zeolite) produces diethyl ether and ethylene with high yields [1]. However, a number of studies report on the possibility to produce other hydrocarbons, in particular aromatics [2] and higher olefins, from ethanol. This process is expected to be similar to the well-established Methanol to Gasoline [3], Methanol to Olefins (MTO) [4,5,6] and Methanol to Propylene (MTP) processes [7], already developed at the industrial level producing olefins from methanol over zeolites and Silico-AluminoPhosphate (SAPO) catalysts.

To produce lower hydrocarbons, such as light olefins, the use of $\mathrm{H}-\mathrm{ZSM}-5$ with a high $\mathrm{SiO}_{2} / \mathrm{Al}_{2} \mathrm{O}_{3}$ ratio and modified ZSM-5 have been considered. Murata et al. [8] obtained high propylene selectivity $(\sim 25 \%)$ at $\mathrm{SiO}_{2} / \mathrm{Al}_{2} \mathrm{O}_{3}$ ratio of 50 , selectivity decreasing with increasing $\mathrm{SiO}_{2} / \mathrm{Al}_{2} \mathrm{O}_{3}$ ratio. A number of studies focus on the effect of crystal sizes [9], porous structure with $\mathrm{NaOH}$-treated [10] of H-ZSM-5 as well as metal addition such as Mg, Fe, Cr, Ce, Co, Zr, Au, W, La, noble metal, 
Molybdenum oxide, $\mathrm{Mo}_{2} \mathrm{C}[11,12,13,14,15,16,17,18,19,20,21]$ on olefins production from ethanol. In particular, while Zr- [20], W-, La- [8,18], La- and La-Mg- [19], Fe- and Ni-modification of H-ZSM5 are reported to enhance the formation of lower olefins from ethanol [15]. Zn, Ga and Pd doped ZSM-5 enhance the formation of aromatics [15,22]. In addition, it is evident that the addition of phosphorus improves the material's catalytic stability (up to 110h) and resistance to coke formation as compared to unmodified H-ZSM-5 [23,24]. In this study, we investigate the catalytic performance of hydrocarbons production from ethanol using $\mathrm{H}-\mathrm{ZSM}-5$ with a $\mathrm{SiO}_{2} / \mathrm{Al}_{2} \mathrm{O}_{3}$ ratio of 50 , and the addition of $\mathrm{H}_{3} \mathrm{PO}_{4}$ as source of $\mathrm{P}$ as well as the successive addition $(\mathrm{P} \rightarrow \mathrm{Fe})$ and $(\mathrm{P} \rightarrow$ $\mathrm{Ni})$. The aim of this work is to look to tuning of product selectivity in ethanol conversion over $\mathrm{H}$ ZSM-5 based zeolite catalysts.

\section{Experimental}

\subsection{Catalyst preparation}

The commercial ammonium form zeolites $\mathrm{NH}_{4}-\mathrm{ZSM}-5$ (CBV 5524G, $\mathrm{SiO}_{2} / \mathrm{Al}_{2} \mathrm{O}_{3}=50$ ) from Zeolyst was used as parent zeolite. $\mathrm{NH}_{4}-\mathrm{ZSM}-5$ was calcined at $973 \mathrm{~K}$ for $6 \mathrm{~h}$ to thermally decompose $\mathrm{NH}_{4}{ }^{+}$ to $\mathrm{H}^{+}$and $\mathrm{NH}_{3(\mathrm{~g})}$, and denoted as $\mathrm{Z}(700)$, for comparison the same parent zeolite was also calcined at $773 \mathrm{~K}$ for $4 \mathrm{~h}$ and denoted as Z(500). Phosphorus modified H-ZSM-5 zeolite was prepared by impregnation of $\mathrm{Z}(700)$ with various amounts of $85 \% \mathrm{H}_{3} \mathrm{PO}_{4}$ (Carlo Erba) following the method in previous study [25], $\mathrm{P}$ content varied from $0.5 \%$ to $6 \%$ wt. All samples were vaporized at $373 \mathrm{~K}$ until drying and then calcined in air at $973 \mathrm{~K}$ for $5 \mathrm{~h}$, P-modified $\mathrm{H}$-ZSM- 5 samples containing $\alpha$ wt $\%$ were labeled as $\alpha P Z$. $\mathrm{Fe}\left(\mathrm{NO}_{3}\right)_{3} \cdot 9 \mathrm{H}_{2} \mathrm{O}$ (Carlo Erba) and $\mathrm{Ni}\left(\mathrm{NO}_{3}\right)_{2} \cdot 6 \mathrm{H}_{2} \mathrm{O}$ (Sigma-Aldrich) were used as metal source, loading of $\mathrm{Fe}$ or $\mathrm{Ni}$ was $1 \%(\mathrm{w} / \mathrm{w})$. The addition of $\mathrm{Fe}$ or $\mathrm{Ni}$ on $\mathrm{H}-\mathrm{ZSM}-5$ and $\mathrm{aPZ}$ was impregnated, metal was added into the mixture of $1 \mathrm{~g}$ zeolite sample and $5 \mathrm{~g}$ distillated water, the mixture was stirred for $3 \mathrm{~h}$ at room temperature then dried and calcined in the same method with P-modified zeolite above. All zeolite samples are summarized in Table 1.

\subsection{Characterization}

2.2.1. FT-IR study

IR spectra were recorded using Nicolet 380 FT-IR spectrometers. Acidity measurements were taken using the pure powders pressed into thin wafers and activated in the IR cell connected with a conventional outgassing/gas-manipulation apparatus at $773 \mathrm{~K}$. The activated samples were contacted with pyridine vapor ( $\mathrm{p}_{\mathrm{Py}} \sim 1$ torr) at room temperature for $15 \mathrm{~min}$; after which the IR spectra of the surface species were collected in continuous evacuation at room temperature with increasing temperature.

2.2.2. TG-DTA study

TG-DTA (Thermogravimetric - Differential Thermal Analysis) was performed using a TG-DSC Netzsch Gerätebau STA 409 (Germany), equipped with a Netztch 410 furnace temperature 
controller system. About $50 \mathrm{mg}$ of sample was placed in a cylindrical alumina crucible of $0.1 \mathrm{ml}$ of volume and $6 \mathrm{~mm}$ of diameter and heated from room temperature until $1073 \mathrm{~K}$ with a nominal heating rate of $10 \mathrm{~K} \mathrm{~min}^{-1}$. The weight was continuously recorded by dedicated software. All the tests were run in static air.

\subsubsection{UV-vis analysis}

UV-vis analysis was performed using a Jasco V570 instrument, equipped with a DR integration sphere for the analysis of fresh catalysts powder. All the spectra were recorded in air at room temperature.

\subsubsection{XRD analysis}

X-ray powder diffraction patterns were carried out with a X-Pert Philips diffractometer using a $\mathrm{Cu}$ Ka radiation.

\subsection{5. $\mathrm{NH}_{3}$-TPD experiment}

$\mathrm{NH}_{3}$-temperature-progammed-desorption (TPD) experiments of investigated samples were carried out by using Nicolet 380 FT-IR spectrometers for desorbed ammonia continuous detection. The mixture of $150 \mathrm{mg}$ of catalyst and $500 \mathrm{mg}$ of sand (50-70 mesh sieved, Sigma-Aldrich, calcined at $1073 \mathrm{~K}$ ) was placed in a tubular flow reactor and pretreated in $\mathrm{N}_{2}$ flow (50 cc/min) at $773 \mathrm{~K}$ for $1 \mathrm{~h}$, adsorption of $\mathrm{NH}_{3}$ at $373 \mathrm{~K}$ for $1 \mathrm{~h}$ by flowing of $1 \% \mathrm{NH}_{3} / \mathrm{He}(40 \mathrm{cc} / \mathrm{min})$ after cooling down the reactor to $373 \mathrm{~K}$ in flow of $\mathrm{N}_{2}$, then desorption of weak or physical adsorbed $\mathrm{NH}_{3}$ in $\mathrm{N}_{2}$ flow at 373 $\mathrm{K}$ for $1.5 \mathrm{~h}$. TPD profiles were obtained under condition of $\mathrm{N}_{2}$ flow $(90 \mathrm{cc} / \mathrm{min})$ with the temperature varying from 373 to $950 \mathrm{~K}$ at $10 \mathrm{~K} \mathrm{~min}^{-1}$.

\subsection{Catalytic experiment}

Catalytic experiments were performed at atmospheric pressure in a tubular flow reactor using the mixture of zeolite and quartz (60-70 mesh sieved) and feeding 7.9\% v/v ethanol in nitrogen. The carrier gas (nitrogen) was passed through a bubbler containing ethanol (99.5\%, Sigma-Aldrich) maintained at constant temperature $(298 \mathrm{~K})$ in order to obtain the desired partial pressures. The temperature in the experiment was varied stepwise from $373 \mathrm{~K}$ to $873 \mathrm{~K}$.

Ethanol conversion is defined as usual:

$\mathrm{X}_{\mathrm{EtOH}}=\left(\mathrm{n}_{\mathrm{EtOH}(\mathrm{in})}-\mathrm{n}_{\mathrm{EtOH}(\mathrm{out})}\right) / \mathrm{n}_{\mathrm{EtOH}(\mathrm{in})}$

While selectivity to product $i$ is defined as follows:

$S_{i}=n_{i} /\left(v_{i}\left(n_{E t O H(i n)}-n_{E t O H(o u t)}\right)\right)$

where $\mathrm{n}_{\mathrm{i}}$ is the moles number of compound $i$, and $\mathrm{v}_{\mathrm{i}}$ is the ratio of stoichiometric reaction coefficients.

The outlet gases were analyzed by a gas chromatograph (GC) Agilent 4890 equipped with a Varian capillary column "Molsieve 5A/Porabond A Tandem" and TCD and FID detectors in series. In order to identify the compounds of the outlet gases, a gas chromatography coupled with mass 
spectroscopy (GC-MS) Thermo Scientific with TG-SQC column (15 m x $0.25 \mathrm{~mm} \times 0.25 \mu \mathrm{m})$ was used.

\section{Results}

\subsection{Characterization of the fresh investigated catalysts}

\subsubsection{IR study of the surface hydroxyl groups}

The IR spectra of the $\mathrm{OH}$ hydroxyl groups $(\mathrm{OHs})$ of zeolite samples are presented in Fig. 1. All samples show three main region bands as usual [26,27]: a strong and sharp $\mathrm{OH}$ stretching band $(\mathrm{vOH})$ at $3742 \mathrm{~cm}^{-1}$ due to weakly acidic terminal silanol groups located on the external zeolite surface, the band at $3606 \mathrm{~cm}^{-1}$ assigned to the bridging hydroxyl Si-OH-Al groups on the inner surface and possessing a strong Brønsted acidity [28,29], one or more bands in the region near $3660 \mathrm{~cm}^{-1}$ corresponding to $\mathrm{OH}$ groups on extraframework aluminium species. All bands tend to reduce in intensity by impregnation of $\mathrm{P}, \mathrm{Ni}$ and $\mathrm{Fe}$. The bridging hydroxyl Si-OH-Al band decreases in intensity significantly after addition of phosphorus, and almost disappears in the case of $6 \mathrm{PZ}$, where a new weak band appears near $3665 \mathrm{~cm}^{-1}$ possibly due to contribution of $\mathrm{P}-\mathrm{OH}$ groups [30]. The bridging hydroxyl Si-OH-Al band of Fe1PZ and Ni1PZ lost intensity remarkably in comparison with $1 \mathrm{PZ}$ catalyst.

\subsubsection{XRD}

XRD patterns of some investigated samples are presented in Fig. 2. All samples exhibited typical H-ZSM-5 zeolite structure without the appearance of any new peak, suggesting that no additional crystalline phases are detectable, as reported previously [24,31]. The intensity of XRD patterns significantly decreases after addition of phosphorus, in particular the main peak at $23.2^{\circ}$ of $6 \mathrm{PZ}$ reduces slightly half of intensity in comparison with parent zeolite, due to the framework defects caused by dealumination [32,33]. In case of addition $1 \% \mathrm{Fe}$ and $1 \% \mathrm{Ni}$ on $\mathrm{H}-\mathrm{ZSM}-5$, the shape of $\mathrm{XRD}$ patterns also is unchanged, in agreement with previous studies [34,35].

\subsubsection{Pyridine adsorption}

The surface acidity of zeolite samples was studied by IR spectroscopy, using pyridine as a probe molecule. Fig. 3 shows the subtraction spectra of pyridine adsorbed on zeolite samples after outgassing at $423 \mathrm{~K}$. All present the features of pyridinium ions (in particular the $8 \mathrm{a}$ band at ca $1637 \mathrm{~cm}^{-1}$, and the $19 \mathrm{a}$ and $19 \mathrm{~b}$ bands at 1545 and $1490 \mathrm{~cm}^{-1}$ ), as the result of their Brønsted acidity. This band decreases in intensity following the addition of $\mathrm{P}$ as well as $\mathrm{Ni}$ and $\mathrm{Fe}$, and have minimum intensity in the case of 6PZ. The features of adsorbed molecular pyridine (i.e. the $19 \mathrm{~b}$ band at 1451-1448 $\mathrm{cm}^{-1}$, together with 8 a bands in the $1615-1595 \mathrm{~cm}^{-1}$ region) show the presence of significant amounts of Lewis acidity on the Z(700) sample, attributed to extraframework Alcontaining species [36], Fe1PZ and, more intense, on Ni1PZ. In contrary, these bands are very weak, if at all, on $1 \mathrm{PZ}$ and $6 \mathrm{PZ}$ samples. This suggests that the addition of phosphorus covers the 
extraframework Alumina-like species and that Fe and Ni cations $[37,38]$ display remarkable Lewis acidity.

\subsubsection{UV-vis study}

The diffuse reflectance UV-vis spectra, recorded in air, of the fresh catalysts are presented in Fig. 4. The spectra of $\alpha P Z$ samples are the same shape of parent zeolite $H-Z S M-5$, showing no definite absorption in the near UV and visible range. In the case of Fe-modified zeolite samples, strong absorption appear in both near UV and visible region (Fig. 4b), arising from $\mathrm{O}^{2-} \rightarrow \mathrm{Fe}^{3+}$ charge transfer and $\mathrm{Fe}^{3+} \mathrm{d} \rightarrow \mathrm{d}$ transitions. The referential $\mathrm{Fe}_{2} \mathrm{O}_{3}$ oxide shows two similar bands at $365 \mathrm{~nm}$ and at $525 \mathrm{~nm}$ corresponding to oligomeric clusters and large $\mathrm{Fe}_{2} \mathrm{O}_{3}$ particles [39], respectively. All Fe-modified zeolite samples show more intense the former band, suggesting the presence of small $\mathrm{Fe}_{2} \mathrm{O}_{3}$-like clusters. The spectra of the Ni-modified zeolite samples also differ from that of parent zeolite mainly in the visible region. The spectra of all Ni-containing zeolites show a broad band near $720 \mathrm{~nm}$, maybe due to contribution of nickel ions in a near tetrahedral coordination [40]. Over $\mathrm{Ni}-\mathrm{P}$ zeolites a new band appears near $450 \mathrm{~nm}$ likely due to a second Nickel species. The spectra, due to $\mathrm{Ni}^{2+} \mathrm{d} \rightarrow \mathrm{d}$ transitions, do not provide evidence of the presence of bulk $\mathrm{Ni}$ oxide, but should be attributed to dispersed cationic Ni species.

\subsection{5. $\mathrm{NH}_{3}$-TPD}

The Fig. 5 presents the $\mathrm{NH}_{3}$-TPD profiles of $\mathrm{H}-\mathrm{ZSM}-5$ and modified catalysts in the temperature range $373-950 \mathrm{~K}$ are shown. Parent zeolite shows two desorption peak: one centered at ca. $500 \mathrm{~K}$ and the other at $675 \mathrm{~K}$, corresponding to weak and strong acid sites, respectively. With increasing phosphorus loading, the intensity of strong acid sites desorption peak decreases significantly, while weak acid sites desorption peak shifts toward higher temperature and slightly increases the intensity. Interestingly, with higher amount of phosphorus addition (6\%), only one peak is observed at intermediate temperature (ca. $610 \mathrm{~K}$ ), although with a pronounced tail towards higher temperature. This behavior compares quite well with the data coming from IR spectra of the $\mathrm{OH}$ groups and pyridine adsorption experiments, showing that strong "zeolitic" Brønsted sites progressively disappear by $\mathrm{P}$ addition, together with extraframework Lewis acid sites, while weaker Brønsted sites of the $\mathrm{POH}$ type form also in the case of $\mathrm{Ni}$ and Fe containing samples the Zeolitic Brønsted sites decrease in amount. The broad and weaker component at ca. $650 \mathrm{~K}$ on Fecontaining samples can be due to the Lewis acidity of $\mathrm{Fe}^{3+}$ while the desorption peak at ca. $850 \mathrm{~K}$ observed for Ni-containing samples suggests that addition of $\mathrm{Ni}$ on $\mathrm{H}-\mathrm{ZSM}-5$ results in few new "very strong" Lewis acid sites.

\subsection{Catalytic conversion of ethanol.}


In Fig. 6 the performances of the starting zeolite catalyst (calcined at $773 \mathrm{~K}$ ) in ethanol conversion upon increasing temperature are reported. The conversion of ethanol becomes detectable at $393 \mathrm{~K}$ and is complete at $523 \mathrm{~K}$. Diethyl ether is essentially the only product until $453 \mathrm{~K}$ while dropping in favor of ethylene whose selectivity rises more than $90 \%$ at $523 \mathrm{~K}$. However, also ethylene selectivity drops at higher temperatures in favour of a number of other hydrocarbons, such as propane, propylene, butene, butane and aromatics. At $573 \mathrm{~K}$ ethylene selectivity drops to $20 \%$ with $80 \%$ selectivity to higher hydrocarbons.

To attempt the massive production of higher hydrocarbons from ethanol on zeolite H-ZSM-5, the catalytic conversions at temperatures higher than $523 \mathrm{~K}$ were investigated. To establish catalyst stability at high temperature, the catalyst was previously calcined at $973 \mathrm{~K}$.

Also over H-ZSM-5 calcined at $973 \mathrm{~K}(\mathrm{Z}(700))$ (Fig. 7), ethanol is totally converted from $573 \mathrm{~K}$, but ethylene selectivity is retained higher than on the zeolite catalyst calcined at $773 \mathrm{~K}(\mathrm{Z}(500))(80 \%)$. However, ethylene selectivity decreases down to near $50 \%$ at $673 \mathrm{~K}$ with corresponding increasing selectivities to light paraffins and other alkenes. However, further increase of the reaction temperature causes a recovery of ethylene selectivity and a drop of other hydrocarbon selectivities over both $Z(700)$ and $Z(500)$ catalysts, where aromatics selectivity is actually very low in these conditions. A very different situation is observed in the case of 6PZ: ethanol reaches complete conversion only at $673 \mathrm{~K}$ (thus showing that $6 \% \mathrm{P}$ decreases strongly the catalytic activity), and the main products are diethyl ether and ethylene at low temperature, and almost only ethylene at high temperature $(\geq 673 \mathrm{~K})$, no other hydrocarbon being observed. Thus over $6 \mathrm{PZ}$ eythylene selectivity is much increased at full ethanol conversion, to $100 \%$.

Fig. 8 shows the main product selectivites with different reactor space time $\left(\mathrm{g}_{\mathrm{cat}} / \mathrm{mol}_{\mathrm{Ethanol}}\right)$ over $\mathrm{Z}(700)$ catalyst after $3.5 \mathrm{~h}$ time-on-stream at $673 \mathrm{~K}$. The ethanol conversion was constant at $100 \%$ but ethylene selectivity decreases remarkably by increasing reaction space time, while the selectivities to $\mathrm{C}_{3} \mathrm{H}_{8}, \mathrm{CH}_{3} \mathrm{CHO}$ and $\mathrm{C}_{5+}$ increase all slightly. Aromatics are not formed at very low $\mathrm{W} / \mathrm{F}\left(0.0064 \mathrm{~kg} \mathrm{~h} \mathrm{~mol}^{-1}\right)$, but are produced progressively more and more at increasing W/F.

To have a look of what happens with the different catalysts we compared in Fig. 9 the product selectivities obtained at $673 \mathrm{~K}$ after $4.5 \mathrm{~h}$ time on stream and $\mathrm{W} / \mathrm{F}=0.0258 \mathrm{~kg} \mathrm{~h} \mathrm{~mol}^{-1}$. In all cases ethanol conversion is $100 \%$. It is quite evident that selectivity to ethylene is increased by $\mathrm{P}, \mathrm{Fe}$ and Fe-P additions up to $90 \%$, while aromatics and $\mathrm{C}_{4}$ selectivities are significantly increased by $\mathrm{Ni}$ and Ni-P addition up to 18 and $16 \%$, respectively. Selectivity to propylene is maximum on nonmodified Z(700) (22\%) being decreased slightly by Ni addition and more by $\mathrm{P}$, Fe and Fe-P addition.

\subsection{Characterization of the exhausted catalysts by TG-DTA}

The activity and stability of catalysts may depend on presence of coke on the surface of catalysts. The amount of deposed coke was calculated by combustion of carbon species of spent catalysts using TG-DTA. Fig. 10a shows the comparison of TG and DTA curves of parent zeolite $Z(700)$ and $\mathrm{P}$-modified zeolite. Increasing the $\mathrm{P}$ content in catalysts, the coke presence, calculated as the 
weight loss in the temperature range $453-973 \mathrm{~K}$, is reduced from $1 \%$ to $0.5 \%$. This means a positive effect in reduction of the coke formation on the surface of catalysts due to phosphorus.

The same effect can be appreciated for Ni-modified zeolite samples. In this case, the carbon coke

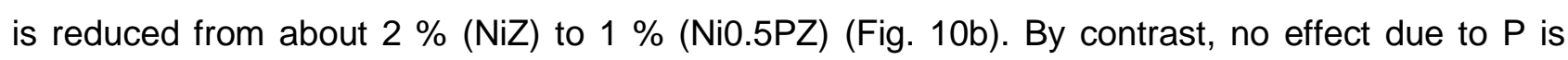
evident in the catalysts with Fe, in which only $1 \%$ of coke is found for almost Fe-modified zeolite samples (Fig. 10c, $d$ and e). In case of $\mathrm{Ni}$ - and Fe-modified zeolite samples, the DTA curve shows two peaks in the temperature region $523-623 \mathrm{~K}$ and $673-873 \mathrm{~K}$ possibly due to two different coke family structures formed on zeolites. The DTA peak at ca. $673-873 \mathrm{~K}$ can be assigned to the combustion of "hard" coke, essentially located in the zeolite cavities [41]. In Fig. 10c, The TG curve indicates that coke formation on $\mathrm{NiZ}$ is higher on that of $\mathrm{FeZ}$, suggesting that Fe-containing catalysts can be more stable than Ni-containing catalysts. However, with co-modification of both $\mathrm{P}$ with $\mathrm{Ni}$ or $\mathrm{Fe}$, the coke formation is similar in all cases (Fig. 10d and e). On the other hand, P is more effective than $\mathrm{Ni}$ and $\mathrm{Fe}$ in the coke reduction on the zeolite samples.

\section{Discussion}

The data reported here allow to correlate the catalytic activity of modified H-ZSM- 5 catalysts with their surface acid properties. As discussed in several papers, the catalytic activity of H-ZSM-5 zeolite in converting ethanol is essentially due to the strength of their zeolitic surface hydroxyl groups [36] well evident in the $\mathrm{OH}$ stretching IR spectra $\left(3606 \mathrm{~cm}^{-1}\right.$, Fig. 1) and in the spectra of pyridine adsorbed as pyridinium ions $\left(1637,1545\right.$ and $1490 \mathrm{~cm}^{-1}$, Fig. 2). While diethyl ether is the main product of ethanol conversion on this zeolite at low temperature, ethylene is the main product at full conversion and higher temperature (500-550 K). However, by further increasing reaction temperature or contact time (W/F) ethylene selectivity drops in favour of higher hydrocarbons, such as propylene, butenes, butanes and aromatics.

The addition of phosphorus on the zeolite decreases the catalytic activity (conversion of ethanol) but increases the selectivity to ethylene up to $>80 \%$ or even $100 \%$ for $6 \% \mathrm{P}$ at full ethanol conversion. This corresponds to the killing of the zeolitic surface hydroxyl groups, for which evidence is provided by $\mathrm{IR}$ spectroscopy in the $\mathrm{OH}$ stretching region, pyridine adsorption and ammonia TPD, and the appearance of weaker Brønsted acidic $\mathrm{POH}$ groups $\left(3665 \mathrm{~cm}^{-1}\right.$, Fig. 1). P addition also results in a lowered deposition of coke, likely associated to increased catalyst stability.

The impregnation with iron produces on the fresh catalyst small $\mathrm{Fe}_{2} \mathrm{O}_{3}$-like clusters (UV-vis spectra) carrying Lewis acidity (IR spectra of adsorbed pyridine) which displace surface OH groups (IR spectra) thus decreasing the number of Brønsted acid sites. The result of this is to improve the selectivity to ethylene with decreasing selectivity to other hydrocarbons. This behavior can be interpreted as being primarily due to the decrease of the amount of Brønsted sites. It is consequently supposed that the overconversion of ethylene to higher hydrocarbons is associated 
not only to the strength of the surface Brønsted sites (the lower the strength, the less the overconversion to higher hydrocarbons), as evidenced by $\mathrm{P}$ modification, but also to the number (the lower the number of sites, the less the overconversion to higher hydrocarbons).

The impregnation with $\mathrm{Ni}$ produces isolated $\mathrm{Ni}$ cations carrying Lewis acidity. The addition of $\mathrm{Ni}$ appears to have the peculiar activity of favoring $\mathrm{C}_{4}$ and aromatics production with decreasing both ethylene and propylene selectivity. This behavior may be associated to the well-known ability of $\mathrm{Ni}$ species to catalyze olefin oligomerization, in particular ethylene oligomerization $[42,43]$. The reduction of the propylene selectivity by $\mathrm{Ni}$ may give an indication on its forming path: it likely arises from cracking of oligomers, catalyzed by strong Brønsted acid sites (in fact it is maximum on unmodified Z(700)) but not by Nickel.

\section{Conclusions.}

The main results of this work are the following:

1. Addition of phosphorus to H-ZSM-5 reduces significantly the acidity of zeolite, thus enhancing selectivity in the formation of ethylene from ethanol conversion, and decreasing its overconversion to higher hydrocarbons. It also reduces the formation of coke.

2. Iron also decreases the acidity by exchanging the protons, and has a similar effect as phosphorus.

3. Ni-modification of the zeolite catalyst also decreases Brønsted acidity but produces active sites for oligomerization, finally producing more $\mathrm{C}_{4}$ and aromatics.

4. The higher selectivity to propylene (no more than $22 \%$ ) is obtained on unmodified H-ZSM5 zeolite and is attributed to the ability of zeolitic protonic sites both to oligomerize ethylene and to crack oligomers.

\section{Acknowledgements}

TKP acknowledges funding by EMMA (Erasmus Mundus Mobility with Asia) in the framework of the EU Erasmus Mundus Action 2. RR thanks the Master SERP-Chem program. 
Table 1. The summary of investigated catalysts

\begin{tabular}{|l|c|c|c|l|}
\hline Notation & $\mathrm{P}(\% \mathrm{wt} / \mathrm{wt})$ & $\mathrm{Fe}(\% \mathrm{wt} / \mathrm{wt})$ & $\mathrm{Ni}(\% \mathrm{wt} / \mathrm{wt})$ & \multicolumn{1}{c|}{ Preparation } \\
\hline $\mathrm{Z}(500)$ & - & - & - & Calcined $\mathrm{NH}_{4}-\mathrm{ZSM}-5 \mathrm{in}$ air at $773 \mathrm{~K}$ for $4 \mathrm{~h}$ \\
\hline $\mathrm{Z}(700)$ & - & - & - & Calcined $\mathrm{NH}_{4}-\mathrm{ZSM}-5 \mathrm{in}$ air at $973 \mathrm{~K}$ for $6 \mathrm{~h}$ \\
\hline $0.5 \mathrm{PZ}$ & 0.5 & - & - & Added $\alpha \% \mathrm{P}$ from $85 \% \mathrm{H}_{3} \mathrm{PO}_{4}$ into $\mathrm{H}-\mathrm{ZSM}-5$, dried $373 \mathrm{~K}$ and \\
calcined in air at $973 \mathrm{~K}$ for $5 \mathrm{~h}$
\end{tabular}




\section{Figure captions}

Fig. 1. FT-IR spectra of investigated catalysts after activation at $773 \mathrm{~K}(\mathrm{vOH}$ region)

Fig. 2. XRD patterns of some investigated catalysts

Fig. 3. FT-IR subtracted spectra of surface species arising from pyridine adsorbed on some investigated catalysts

Fig. 4. UV-vis spectra of fresh investigated catalysts

Fig. 5. $\mathrm{NH}_{3}$-TPD profiles of some investigated catalysts

Fig. 6. Ethanol conversion and product selectivities as a function of reaction temperature. Condition: $0.5 \mathrm{~g}$ of zeolite catalyst calcined at $773 \mathrm{~K}$ with $\mathrm{W} / \mathrm{F}=0.0325 \mathrm{~kg} \mathrm{~h} \mathrm{~mol}^{-1}$.

Fig. 7. Ethanol conversion and product selectivities as a function of reaction temperature. Condition: $0.1 \mathrm{~g}$ of zeolite and $0.1 \mathrm{~g}$ of quartz with $\mathrm{W} / \mathrm{F}=0.0129 \mathrm{~kg} \mathrm{~h} \mathrm{~mol}^{-1}$

Fig. 8. Product selectivities as a function of reactor space time over $Z(700)$ catalyst after $3.5 \mathrm{~h}$ time-on-stream at $673 \mathrm{~K}$.

Fig. 9. Plots of (a) $\mathrm{C}_{2} \mathrm{H}_{4}$ selectivity vs propylene $+\mathrm{C}_{4}$ selectivity; (b) the ratio of propylene/aromatics vs the ratio of propylene/ethylene; (c) the ratio of $\mathrm{C}_{4}$ /aromatics vs the ratio of $\mathrm{C}_{4}$ /ethylene; (d) aromatics selectivity vs propylene+ $+\mathrm{C}_{4}$ selectivity; (e) selectivity to propylene vs the ratio of propylene/ethylene; and (f) selectivity to $\mathrm{C}_{4}$ vs the ratio of $\mathrm{C}_{4}$ /ethylene. All data here in selectivity after $4.5 \mathrm{~h}$ time-on-stream at $673 \mathrm{~K}$ with $0.0064 \mathrm{~kg} \mathrm{~h} \mathrm{~mol}^{-1}$.

Fig. 10. TG-DTA curves of spent zeolite samples after $7.5 \mathrm{~h}$ time-on-stream at $673 \mathrm{~K}$, under air flow. 


\section{References}

[1] M. Zhang and Y. Yu, Dehydration of Ethanol to Ethylene, Ind. Eng. Chem. Res. 52 (2013) 9505-9514.

[2] A.T. Aguayo, A.G. Gayubo, A.M. Tarrío, A. Atutxa, J. Bilbao, Study of operating variables in the transformation of aqueous ethanol into hydrocarbons on an HZSM-5 zeolite, J. Chem. Technol. Biotechnol. 77 (2002) 211-216.

[3] http://www.exxonmobil.com/Apps/RefiningTechnologies/files/sellsheet $09 \mathrm{mtg}$ brochure.pdf (Accessed Jan 8, 2015)

[4] J.Q. Chen, A. Bozzano, B. Glover, T. Fuglerud, S. Kvisle, Recent advancements in ethylene and propylene production using the UOP/Hydro MTO process, Catal. Today 106 (2005) 103-107.

[5] P.R. Pujadó and J.M. Andersen, Handbook of petroleum refinery processes, in: R.A. Meyers (Ed.), McGraw Hill, 2006, p. 15.3-14.

[6] J.M. Andersen, Handbook of petrochemicals production processes, in: R.A. Meyers (Ed.), McGraw Hill, 2005, p. 10.15-26.

[7] W. Liebner, Handbook of petrochemicals production processes, in: R.A. Meyers (Ed.), McGraw Hill, 2005, p. 10.3-14.

[8] K. Murata, M. Inaba, I. Takahara, Effects of surface modification of H-ZSM-5 catalysts on direct transformation of ethanol into lower olefins, J. Japan Pet. Inst. 51 (2008) 234-239.

[9] T. Meng, D. Mao, Q. Guo, G. Lu, The effect of crystal sizes of HZSM-5 zeolites in ethanol conversion to propylene, Catal. Commun. 21 (2012) 52-57.

[10] A.G. Gayubo, A. Alonso, B. Valle, A.T. Aguayo, J. Bilbao, Selective production of olefins from bioethanol on HZSM-5 zeolite catalysts treated with $\mathrm{NaOH}$, Appl. Catal. B Environ. 97 (2010) 299306.

[11] J. Bi, M. Liu, C. Song, X. Wang, X. Guo, $\mathrm{C}_{2}-\mathrm{C}_{4}$ light olefins from bioethanol catalyzed by Cemodified nanocrystalline HZSM-5 zeolite catalysts, Appl. Catal. B Environ. 107 (2011) 68-76.

[12] V. Calsavara, M.L. Baesso, N.R.C. Fernandes-Machado, Transformation of ethanol into hydrocarbons on ZSM-5 zeolites modified with iron in different ways, Fuel 87 (2008) 1628-1636.

[13] Y. Han, C. Lu, D. Xu, Y. Zhang, Y. Hu, H. Huang, Molybdenum oxide modified HZSM-5 catalyst: Surface acidity and catalytic performance for the dehydration of aqueous ethanol, Appl. Catal. A Gen. 396 (2011) 8-13.

[14] M. Inaba, K. Murata, M. Saito, I. Takahara, Production of olefins from ethanol by Fe-supported zeolite catalysts, Green Chem. 9 (2007) 638-646.

[15] M. Inaba, K. Murata, M. Saito, I. Takahara, Ethanol conversion to aromatic hydrocarbons over several zeolite catalysts, React. Kinet. Catal. Lett. 88 (2006) 135-142.

[16] M. Inaba, K. Murata, I. Takahara, Effect of Fe-loading and reaction temperature on the production of olefins from ethanol by Fe/H-ZSM-5 zeolite catalysts, React. Kinet. Catal. Lett. 97 (2009) 19-26. 
[17] M. Inaba, K. Murata, I. Takahara, K. Inoue, Production of $\mathrm{C}_{3+}$ Olefins and Propylene from Ethanol by Zr-Modified H-ZSM-5 Zeolite Catalysts, Adv. Mater. Sci. Eng. 2012 (2012) 1-7. doi:10.1155/2012/293485

[18] K. Inoue, M. Inaba, I. Takahara, K. Murata, Conversion of Ethanol to Propylene by H-ZSM-5 with $\mathrm{Si} / \mathrm{Al}_{2}$ Ratio of 280, Catal. Letters 136 (2010) 14-19.

[19] K. Inoue, K. Okabe, M. Inaba, I. Takahara, K. Murata, Metal modification effects on ethanol conversion to propylene by $\mathrm{H}-\mathrm{ZSM}-5$ with $\mathrm{Si} / \mathrm{Al}_{2}$ ratio of 150 , React. Kinet. Mech. Catal. 101 (2010) 477-489.

[20] Z. Song, W. Liu, C. Chen, A. Takahashi, T. Fujitani, Production of propylene from ethanol over ZSM-5 co-modified with zirconium and phosphorus, React. Kinet. Mech. Catal. 109 (2013) 221231.

[21] A. Széchényi, R. Barthos, F. Solymosi, Aromatization of ethanol on $\mathrm{Mo}_{2} \mathrm{C} / \mathrm{ZSM}$ catalysts, Catal. Letters 110 (2006) 85-89.

[22] S.K. Saha, S. Sivasanker, Influence of Zn- and Ga-doing on conversion of ethanol to hydrocarbons over ZSM-5, Catal. Letters 15 (1992) 413-418.

[23] K. Ramesh, L. Hui, Y. Han, A. Borgna, Structure and reactivity of phosphorous modified HZSM-5 catalysts for ethanol dehydration, Catal. Commun. 10 (2009) 567-571.

[24] Z. Song, A. Takahashi, I. Nakamura, T. Fujitani, Phosphorus-modified ZSM-5 for conversion of ethanol to propylene, Appl. Catal. A Gen. 384 (2010) 201-205.

[25] D.V. Vu, Y. Hirota, N. Nishiyama, Y. Egashira, K. Ueyama, High Propylene Selectivity in Methanol-to-olefin Reaction over H-ZSM-5 Catalyst Treated with Phosphoric Acid, J. Japan Pet. Inst. 53 (2010) 232-238.

[26] T. Armaroli, L.J. Simon, M. Digne, T. Montanari, M. Bevilacqua, V. Valtchev, J. Patarin, G. Busca, Effects of crystal size and Si/Al ratio on the surface properties of H-ZSM-5 zeolites, Appl. Catal. A Gen. 306 (2006) 78-84.

[27] K. Hadjiivanov, Chapter Two - Identification and Characterization of Surface Hydroxyl Groups by Infrared Spectroscopy, Adv. Catal. 57 (2014) 99-318.

[28] M. Bevilacqua, T. Montanari, E. Finocchio, G. Busca, Are the active sites of protonic zeolites generated by the cavities?, Catal. Today 116 (2006) 132-142.

[29] N. Brodu, M.-H. Manero, C. Andriantsiferana, J.-S. Pic, H. Valdés, Role of Lewis acid sites of ZSM-5 zeolite on gaseous ozone abatement, Chem. Eng. J. 231 (2013) 281-286.

[30] H.E. van der Bij and B.M. Weckhuysen, Local silico-aluminophosphate interfaces within phosphated H-ZSM-5 zeolites, Phys. Chem. Chem. Phys. 16 (2014) 9892-9903.

[31] M. Inaba, K. Murata, I. Takahara, K. Inoue, Production of olefins from ethanol by Fe and/or Pmodified H-ZSM-5 zeolite catalysts, J. Chem. Technol. Biotechnol. 86 (2011) 95-104. 
[32] J.Q. Zhuang, D. Ma, G. Yang, Z.M. Yan, X.C. Liu, X.M. Liu, X.W. Han, X.H. Bao, P. Xie, Z.M. Liu, Solid-state MAS NMR studies on the hydrothermal stability of the zeolite catalysts for residual oil selective catalytic cracking, J. Catal. 228 (2004) 234-242.

[33] G. Zhao, J. Teng, Z. Xie, W. Jin, W. Yang, Q. Chen, Y. Tang, Effect of phosphorus on HZSM-5 catalyst for $\mathrm{C}_{4}$-olefin cracking reactions to produce propylene, J. Catal. 248 (2007) 29-37.

[34] J. Lu, Y. Liu, N. Li, Fe-modified HZSM-5 catalysts for ethanol conversion into light olefins, J. Natural Gas Chem. 20 (2011) 423-427.

[35] A.G. Gayubo, A. Alonso, B. Valle, A.T. Aguayo, M. Olazar, J. Bilbao, Kinetic modelling for the transformation of bioethanol into olefins on a hydrothermally stable Ni-HZSM-5 catalyst considering the deactivation by coke, Chem. Eng. J. 167 (2011) 262-277.

[36] T.K. Phung, G. Busca, On the Lewis acidity of protonic zeolites, Appl. Catal. A Gen., In press. doi:10.1016/j.apcata.2014.11.031

[37] E. Jóna, M. Kubranová, A. Sirota. M. Kopcová, Thermal and infrared study of desorption of pyridine and pyridine derivatives from Ni-exchanged Montmorillonite, J. Therm. Anal. Cal. 63 (2001) 807-813.

[38] Y. Wan, W. Zhao, Y. Tang, L. Li, H. Wang, Y. Cui, J. Gu, Y. Li, J. Shi, Ni-Mn bi-metal oxide catalysts for the low temperature SCR removal of $\mathrm{NO}$ with $\mathrm{NH}_{3}$, Appl. Catal. B Environ. 148-149 (2014) 114-122.

[39] M. Santhosh Kumar, M. Schwidder, W. Grünert, U. Bentrup, A. Brückner, Selective reduction of NO with Fe-ZSM-5 catalysts of low Fe content: Part II. Assessing the function of different Fe sites by spectroscopic in situ studies, J. Catal. 239 (2006) 173-186.

[40] B. Pawelec, R. Mariscal, R.M. Navarro, J.M. Campos-Martin, J.L.G. Fierro, Simultaneous 1pentene hydroisomerisation and thiophene hydrodesulphurisation over sulphided Ni/FAU and Ni/ZSM-5 catalysts, Appl. Catal. A Gen. 262 (2004) 155-166.

[41] A.R. Pradhan, J.F. Wu, S.J. Jong, T.C. Tsai, S.B. Liu, An ex situ methodology for characterization of coke by TGA and ${ }^{13} \mathrm{C}$ CP-MAS NMR spectroscopy, Appl. Catal. A Gen. 165 (1997) 489-497.

[42] Y. Chauvin, D. Commereuc, F. Hugues, J. Thivolle-Cazat, Nickel-based heterogeneous catalysts for olefin oligomerization: I. Support and anion effects, Appl. Catal. 42 (1988) 205-216. [43] H. Kurokawa, K. Miura, K. Yamamoto, T. Sakuragi, T. Sugiyama, M. Ohshima, H. Miura, Oligomerization of Ethylene to Produce Linear a-Olefins Using Heterogeneous Catalyst Prepared by Immobilization of $\alpha$-Diiminenickel(II) Complex into Fluorotetrasilicic Mica Interlayer, Catal. 3 (2013) 125-136. 
Fig. 1

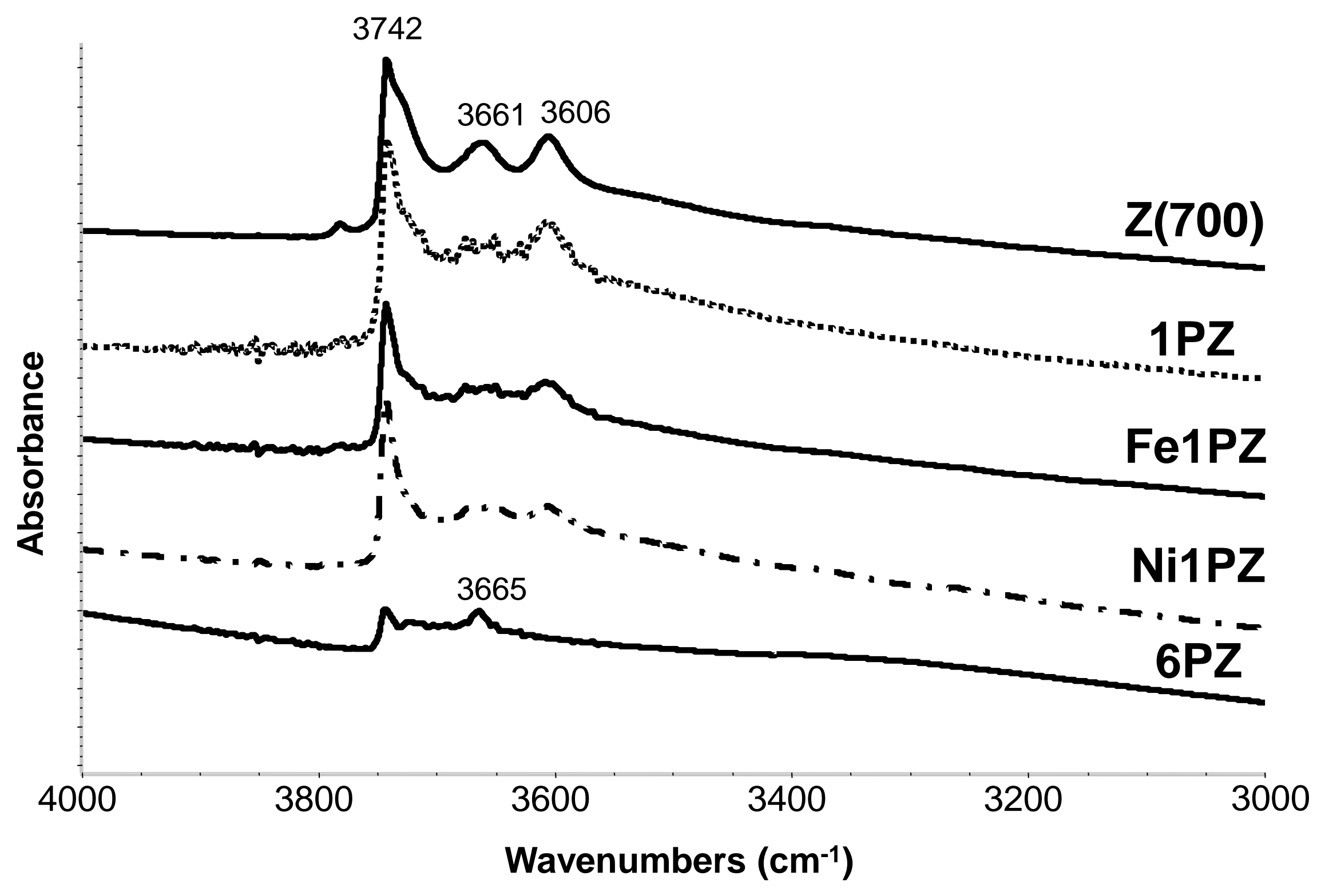


Fig. 2

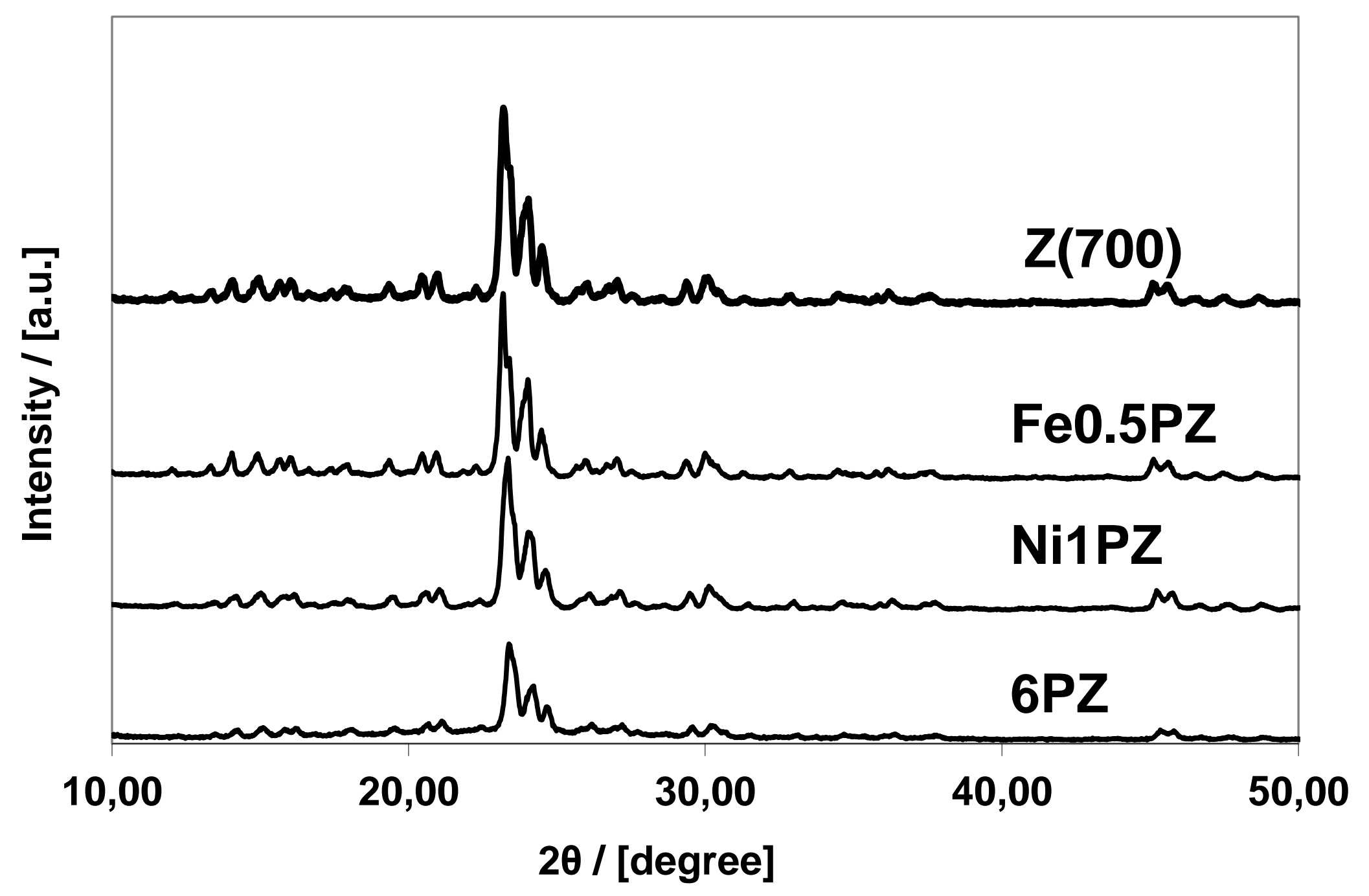


Fig. 3.

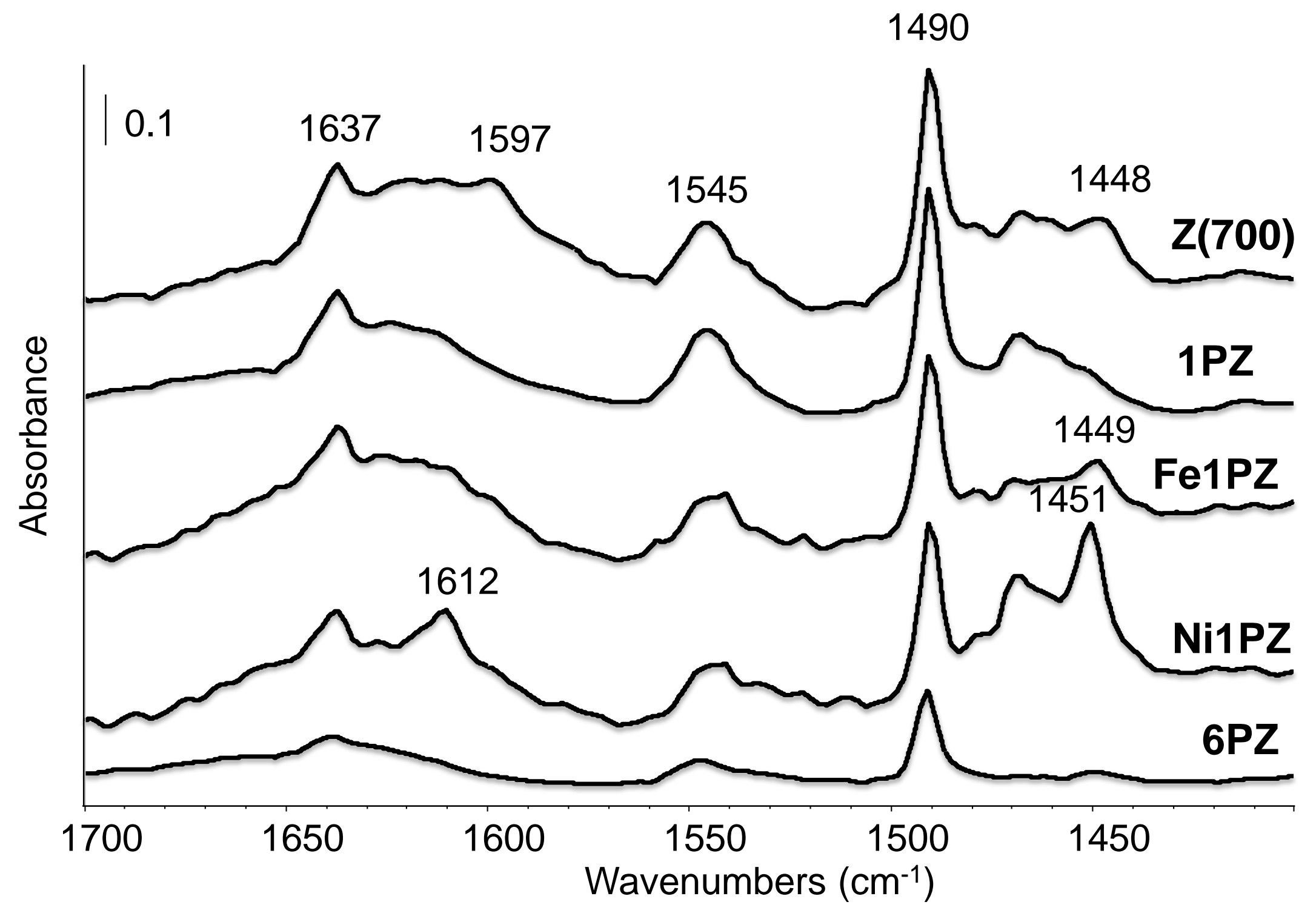


Fig. 4.
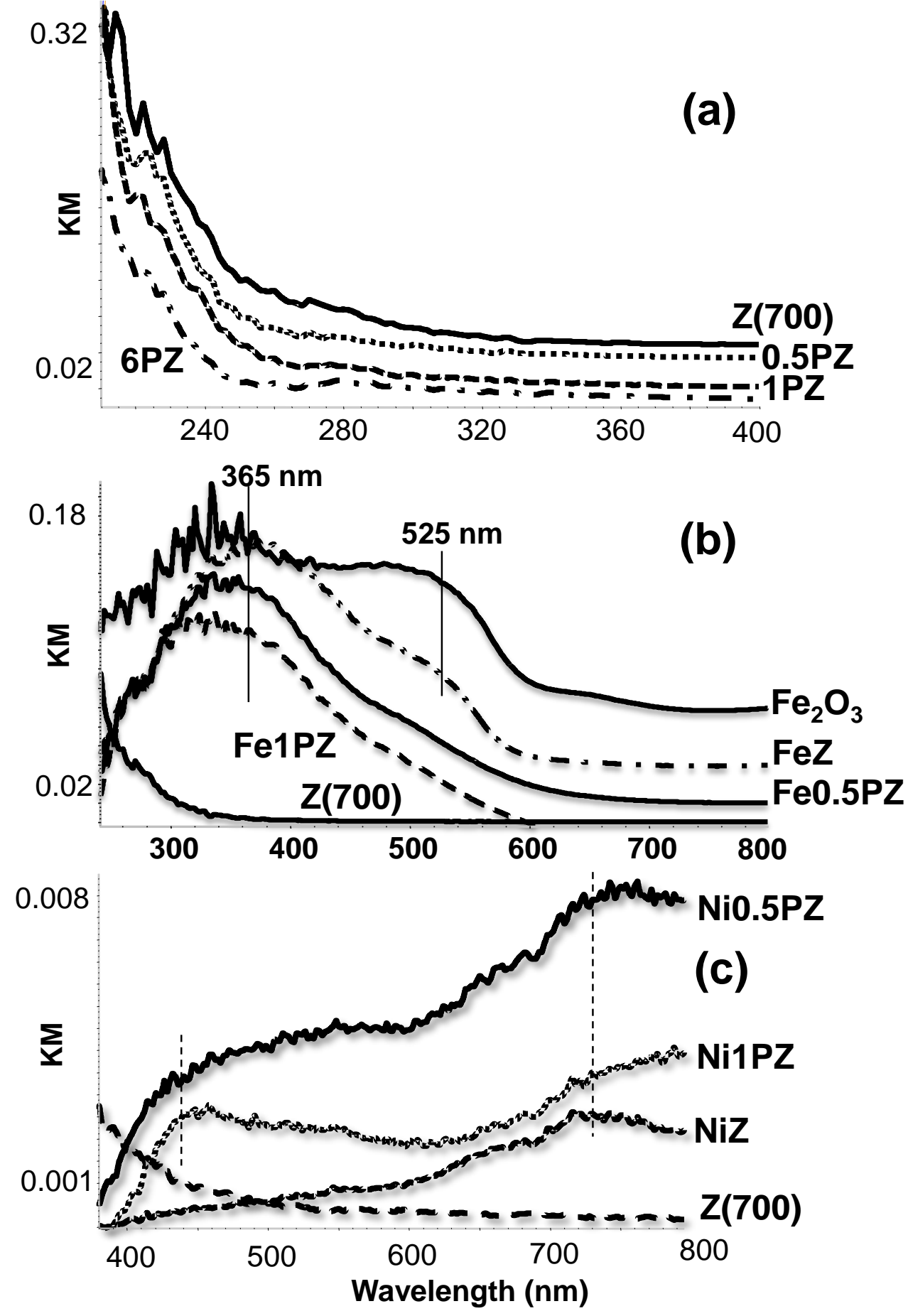
Fig. 5.

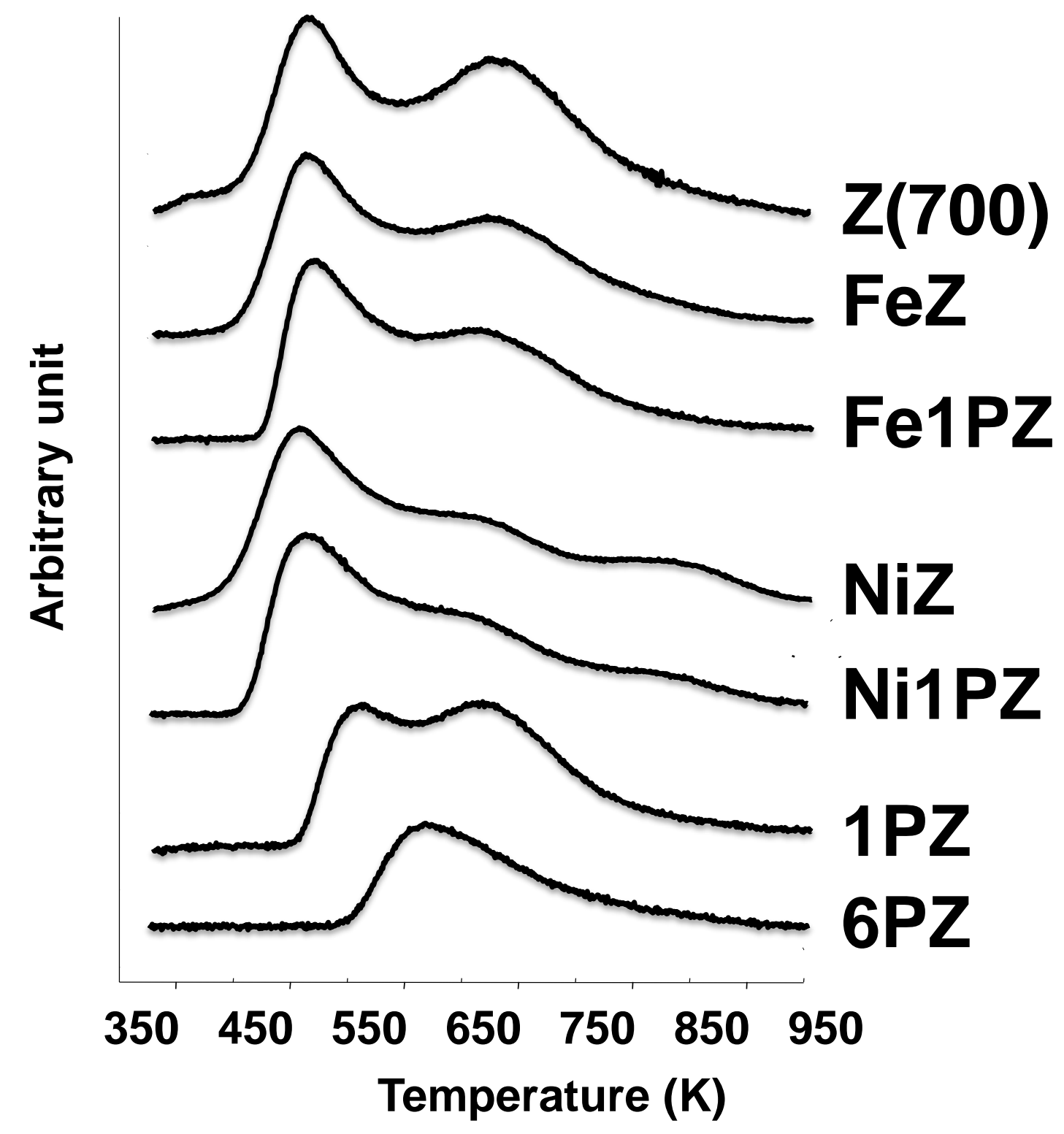


Figure 6.

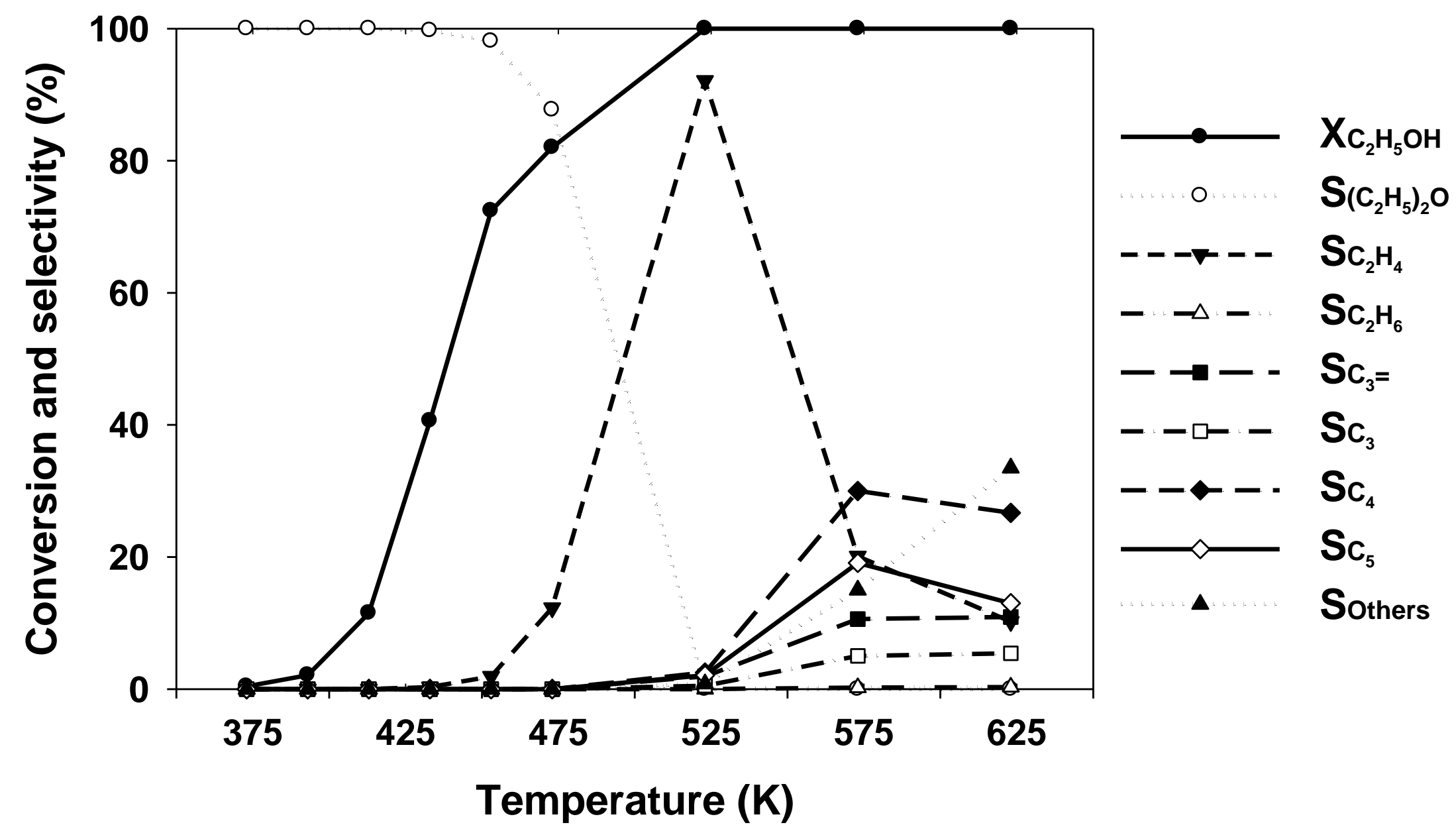




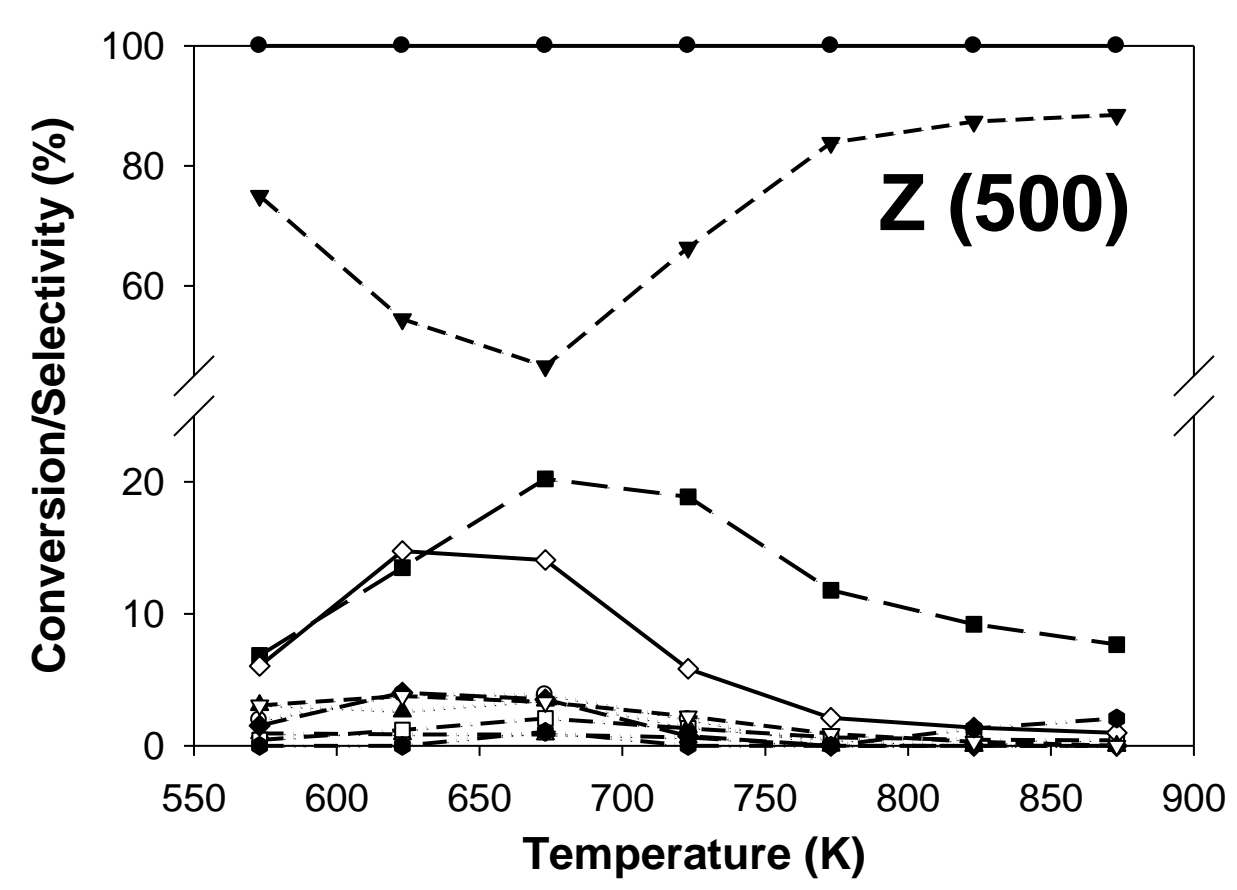

$\mathrm{XC}_{2} \mathrm{H}_{5} \mathrm{OH}$

Figure 7
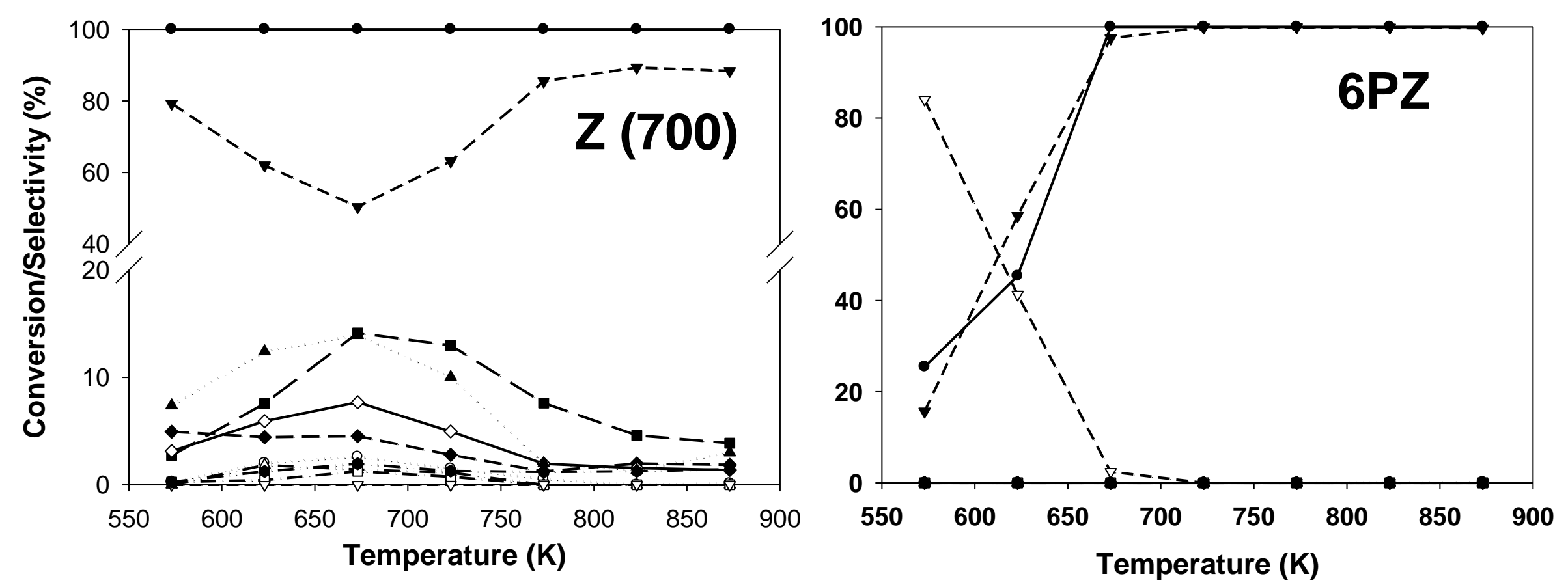
Figure 8.

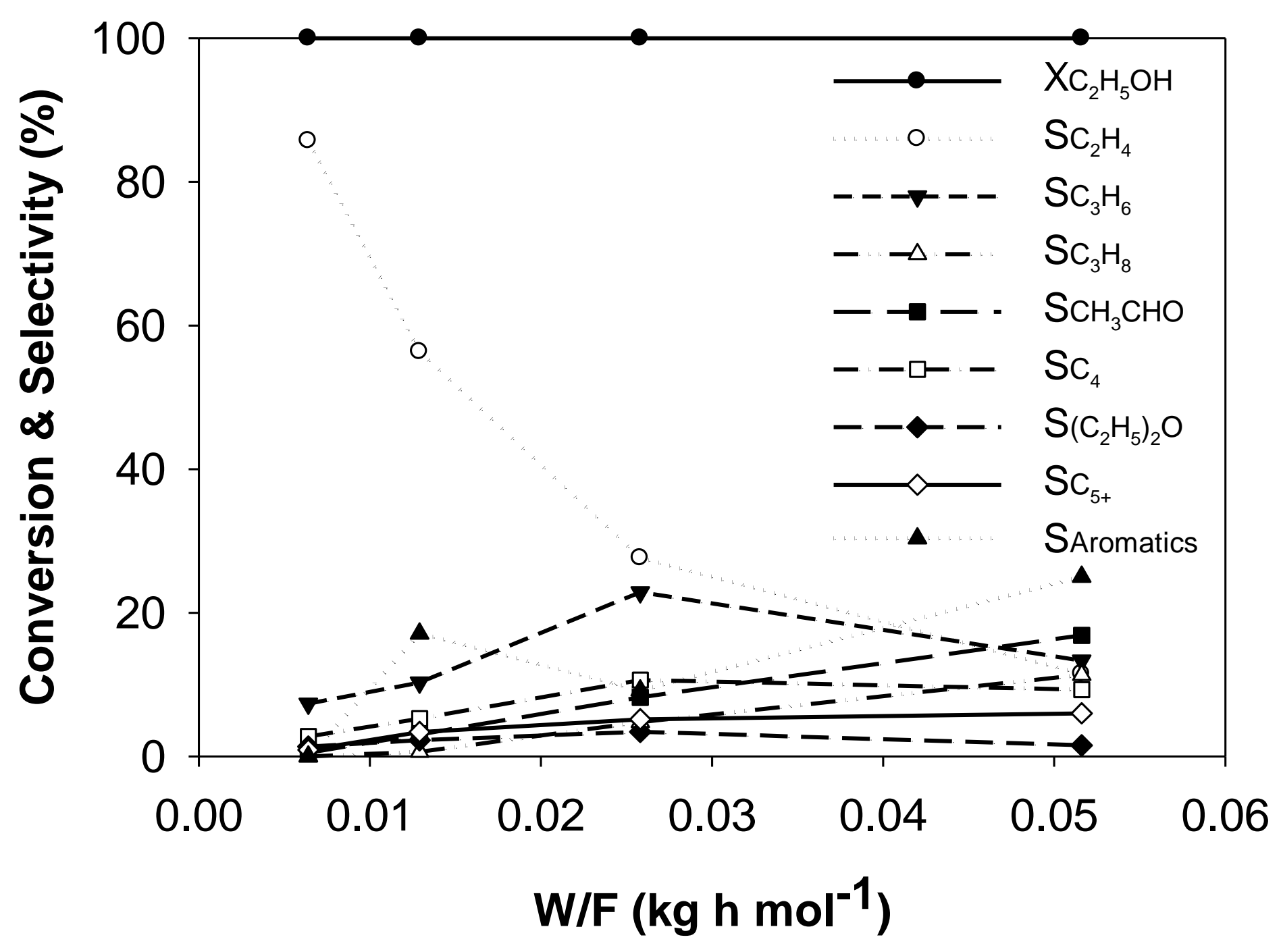



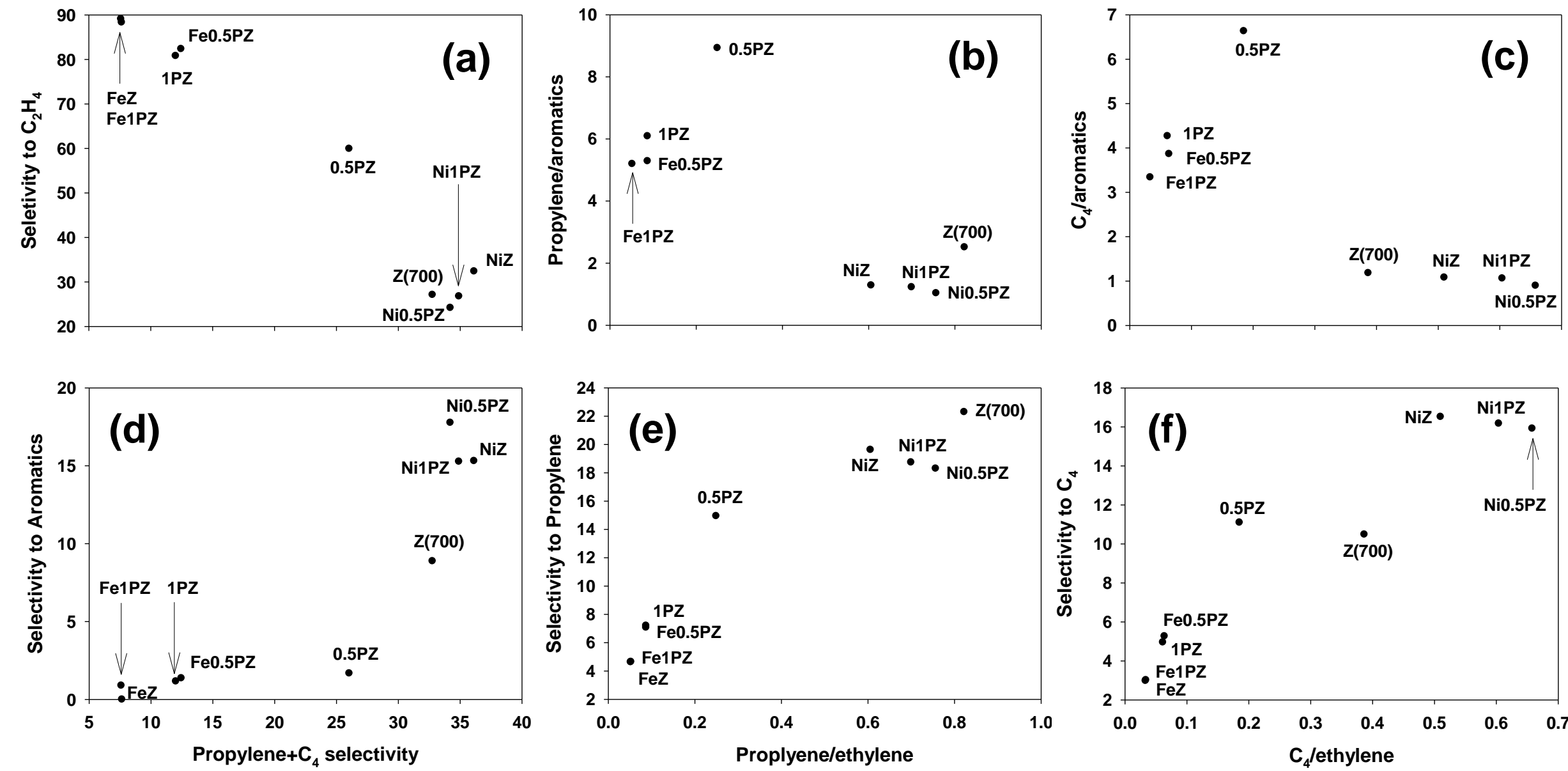
Fig. 10.

a

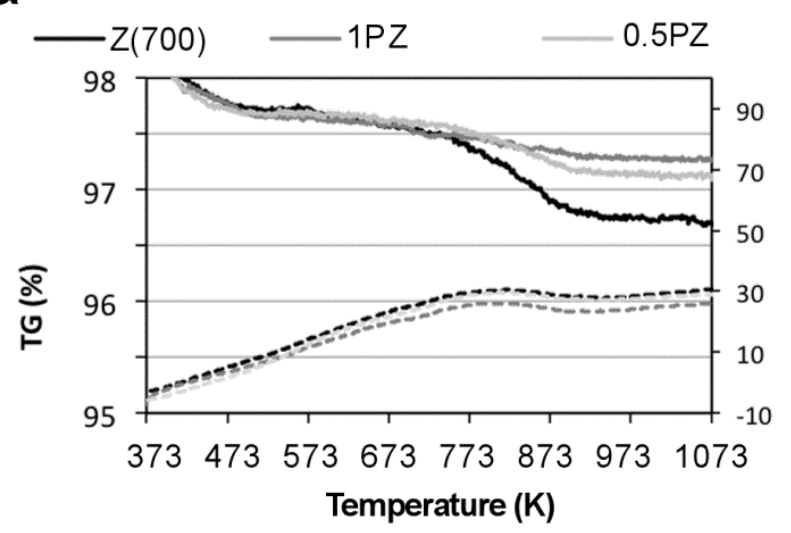

C
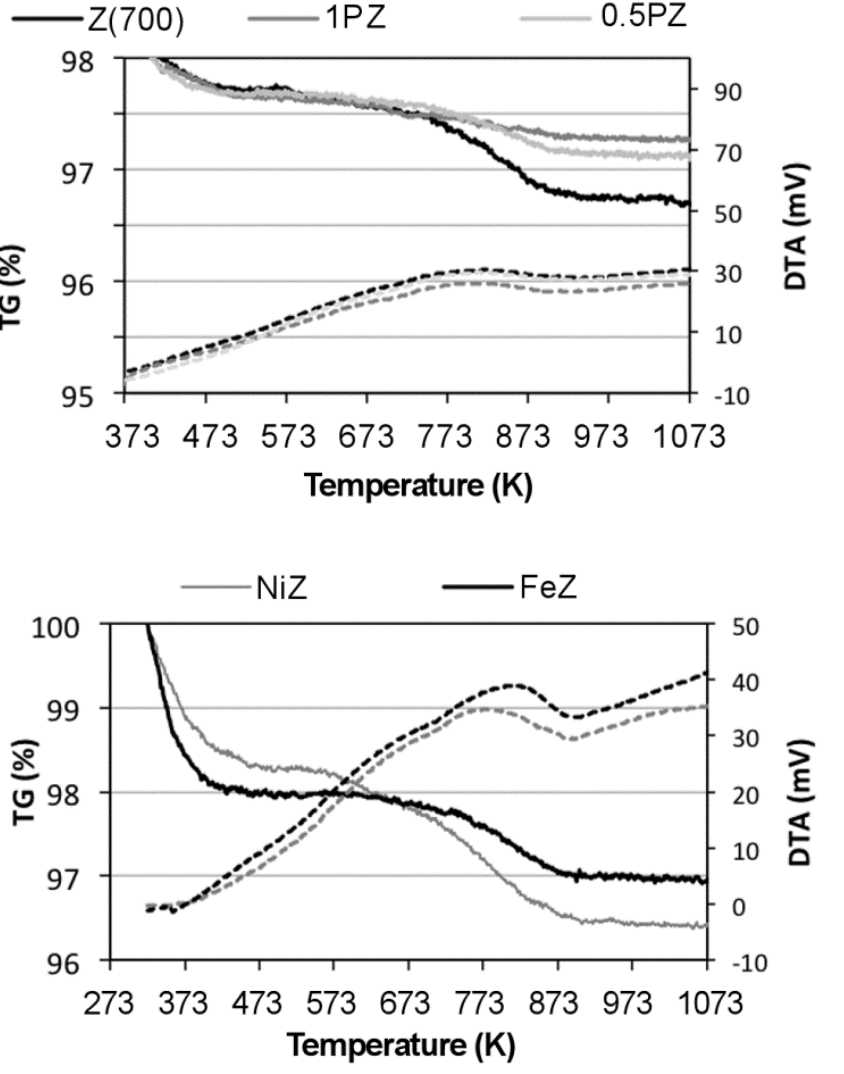
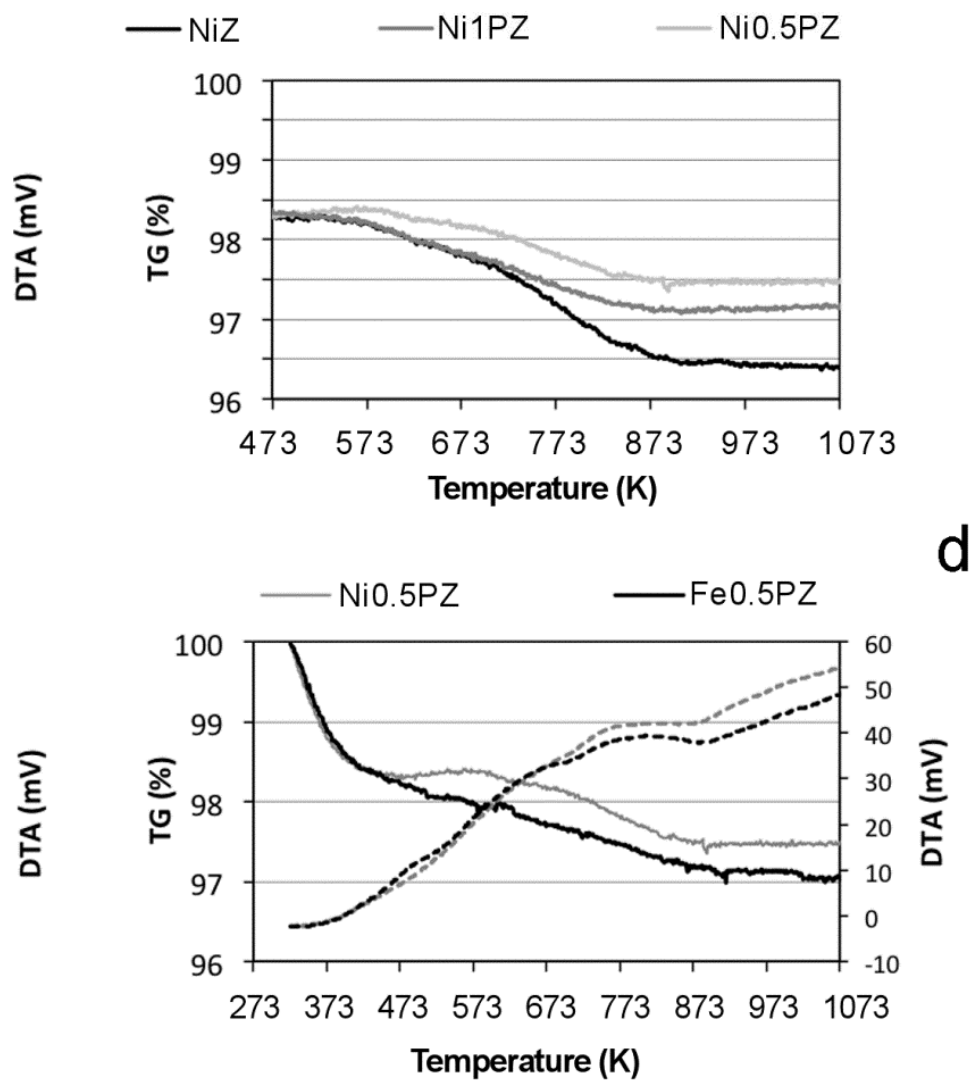

b

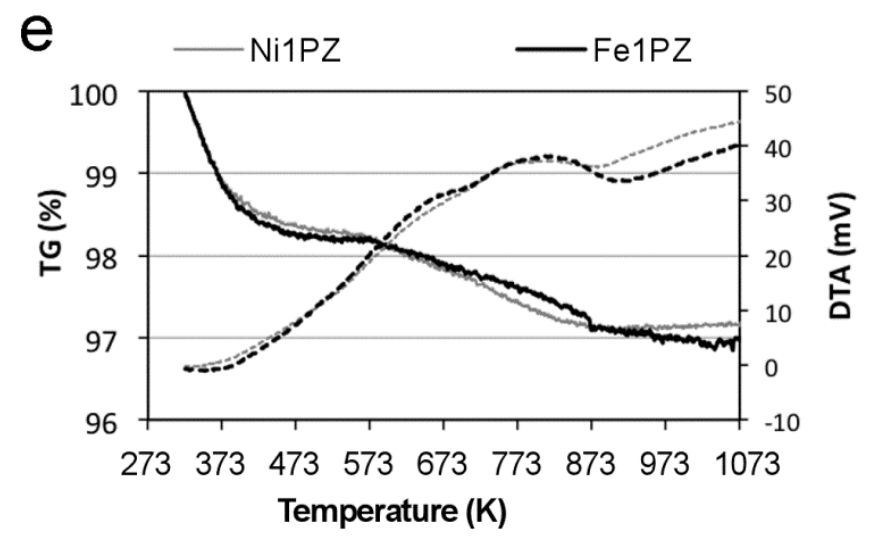

